This is a self-archived version of an original article. This version may differ from the original in pagination and typographic details.

Author(s): Kedra, Joanna

Title: What does it mean to be visually literate? : Examination of visual literacy definitions in a context of higher education

Year: 2018

Version: Accepted version (Final draft)

Copyright: @ Taylor \& Francis, 2018.

Rights: In Copyright

Rights url: http://rightsstatements.org/page/lnC/1.0/?language=en

Please cite the original version:

Kedra, J. (2018). What does it mean to be visually literate? : Examination of visual literacy definitions in a context of higher education. Journal of Visual Literacy, 37(2), 67-84.

https://doi.org/10.1080/1051144X.2018.1492234 
The Version of Record of this manuscript has been published and is available in:

Kędra, J. (2018). What does it mean to be visually literate? Examination of visual literacy definitions in a context of higher education, Journal of Visual Literacy, 37(2), 67-84, DOI: 10.1080/1051144X.2018.1492234.

\title{
What does It Mean to Be Visually Literate? - Examination of Visual Literacy Definitions in a Context of Higher Education
}

\begin{abstract}
Competency in visual literacy (VL) is crucial for effective visual communication, and thus, for living and working in a visually saturated environment. However, VL across disciplines is still marginalized in higher education curricula. This tendency is partly caused by the lack of knowledge and agreement on what it means to be visually literate. This study juxtaposes and evaluates eleven VL definitions, selected as the most relevant for higher education practitioners and coined from 1969 (the first one) to 2013 (the most recent one). The study further proposes three lists of VL skills with thematic categories. Visual reading skills cover interpretation, analysis and understanding, visual perception, evaluation, knowledge of grammar and syntax and visual-verbal-visual translation. Visual writing skills cover visual communication, visual creation and image production and image use. Other VL skills include visual thinking, visual learning and applied image use. Additionally, the study indicates the types of visuals that can be used in visual education. It is suggested to close the debate over the concept of VL. Instead, based on the proposed lists of VL skills, a method of VL assessment can be created.
\end{abstract}

\section{Keywords}

visual literacy, visual literacy in education practice, higher education, visual literacy skills, visual literacy definition 


\section{Introduction}

Contemporary literacy is no longer simply the ability to read and write, but is determined by multi-literacies, including digital, visual, multimodal, and many other literacies. Literacy also has a multidimensional aspect (Riddle, 2009, p. 4), in that information and knowledge come from various sources and directions, among which visual imagery often plays an important role. Pictorial representations are predominant modes of daily communication, and skills in visual reading and writing are therefore essential for full participation in any communication process (ACRL, 2011).

Although university education still heavily relies on texts, recent years have shown greater recognition of the importance of visual education. Felten (2008) perceives visual literacy (VL) as the fundamental element of liberal education. Indeed, the omnipresence of digital technologies caused an increase in educators' awareness of the emergence of new literacies in addition to conventional alphabetic literacy. Studies have focused on the need for reviewing curricula to better serve the current needs of the networked digital society (Avgerinou, 2009; Ervine, 2016). Educators (Bleed, 2005; Hattwig, Bussert, Medaille, \& Burgess, 2013), within the frames of various international associations are calling for the introduction of visually oriented teaching in all fields of study. Some research has emerged that include guidelines and classroom activities (e.g. Brumberger \& Northcut, 2013; Kędra, 2016; Serafini, 2014). One attempt to promote the concept of VL is the Common European Framework of Reference for Visual Literacy (Wagner \& Schönau, 2016), which a group of scholars and educators in arts and art education created. As such, the framework is yet another compilation of studies using a notion of VL, but applying it solely in a context of art education, barely answering the question of what it means to be visually literate.

Furthermore, several educational organizations and scholarly associations, for instance, the International Visual Sociology Association, the International Sociology Association, the European Communication Research and Education Association's Temporary Working Group 'Visual Cultures' and the International Communication Association have recently raised and discussed issues related to visual pedagogies in workshops and conferences worldwide. Their proposals are usually discipline-specific, applying VL as a flexible umbrella term. Thus, VL is used as one of the skills belonging to media literacy, digital literacy and multi- or multimodal literacy. I suggest that in the context of contemporary 
digitally mediated visual communication, VL deserves individual recognition and more attention. My focus is on educational practice in higher education, specifically in university education.

In 1968, John Debes coined the term visual literacy and formulated one of its first definitions (Debes, 1969). Since then, VL has spread across disciplines and contexts, gaining various definitions, but lacking coherent theory either as a concept or as an academic field (Avgerinou \& Pettersson, 2011). One of the first teaching guidelines for VL was proposed by Fransecky and Debes (1972). Four decades later scholars address VL in the context of rapid changes in the media landscape and the development of new technologies (Brumberger, 2011; Brumberger \& Northcut, 2013; Felten, 2008; Hattwig et al., 2013; Pettersson, 2018). Avgerinou (2009) argues that for the 21 st century digital environment reviewing VL is "more than critical" (p. 31). Pettersson (2018) provides a broad chronological review of VL definitions across fields and disciplines. His review covers forty-four years of VL definitions from Debes (1969) to the Visual Literacy Standards for Higher Education (Hattwig et al., 2013). Pettersson's review primarily shows the multidisciplinarity of VL as a field and its inner-diversity as a concept. As such, the review is sufficient for advancing VL theory, but insufficient for visual education practitioners.

The lack of coherence concerning a VL definition should be perceived as an outstanding feature of this multidisciplinary field. Instead of endlessly, although sometimes significantly, revising and compiling studies on VL, I propose to turn the focus toward practical application of VL theory into education. Specifically, I think about university education and the improvement of basic curricula across fields of study by adding VL as one of the learning objectives.

Little, Felten and Berry (2015) suggest that learning to look is a quite difficult task, because seeing is perceived as something natural, and thus should not require any additional training. Due to this line of thinking in college and university education "too few students are afforded the opportunity to develop their visual skills" (Little et al., 2015, p. 2). Instead, tertiary education focuses on written texts and their interpretations, using images as illustrations rather than as a source of knowledge or a teaching method. On the other hand, and due to the lack of agreement upon VL theory, it is difficult to indicate what kinds of VL skills should learners develop as part of their basic education. 
In this study, I attempt to answer the core question of What does it mean to be visually literate? What are the skills that a visually literate individual should possess and demonstrate, especially in a context of visually mediated communication, digital technologies and new media? My interest is in the VL abilities of young adults. Thus, my reflection on VL is positioned within the context of higher education that ought to prepare learners to live and work in the contemporary visually saturated environment. By reviewing and juxtaposing skills, abilities and competences extracted from various definitions of VL, I will compile a list of educational requirements for the visually literate individual. Competencies are enumerated extensively, but not exhaustively. Various skills can be performed with different intensity among learners, regarding their knowledge and experience. By finding common grounds between various definitions of VL, and thus, answering the core question, a step forward towards creating a method of assessment of VL can be achieved.

\section{A Struggle over the (Right) Term}

In the context of visual learning, several terms are used as paradigms for studying visuals depending on their disciplinary roots. Scholars refer to visual communication, visual literacy, digital visual literacy (Spalter \& van Dam, 2008), image literacy (Emanuel, Baker \& Challons-Lipton, 2014, 2016), media literacy, multimodal literacy (Serafini, 2014), multiliteracies, information design (Pettersson, 2018), visual competency (Müller, 2008) and visual competencies (Griffin, 2008). Many of these terms overlap, but some are discussed as opposite to each other (Chauvin, 2003; Griffin, 2008). There are also scholars who are more in favor of literacies instead of a palette of literacy. Provenzo, Goodwin, Lipsky and Sharpe (2011), for instance, argue for the term alternative literacies to cover all types of literacies. However, this term can be misleading as it indicates that any other than conventional literacy is only an option, which can lead to the assumption that VL is a choice rather than a basic requirement for contemporary education. Nevertheless, Provenzo et al. (2011) further indicate that multi- or alternative literacies have the educational potential to empower learners ( $\mathrm{p}$. xxiv) by helping them to express freely in alternative ways, or to develop their skills in conventional literacy.

Although a variety of literacies have been listed as necessary requirements for $21 \mathrm{st}$ century life, "visual literacy seems to be among the most critical ones" (Avgerinou, 2009, p. 32). I also perceive it as the most crucial for education. However, favoring one concept over 
the others will not help to simplify the discussion of today's literacies, especially due to the persistent lack of cohesion within VL theory (Avgerinou \& Pettersson, 2011). This lack of cohesion is mostly caused by the lack of agreement on a definition for VL. The concept is continually being re-defined from various disciplinary perspectives. Brill, Kim and Branch (2007, p. 57) call for "an operational definition of visual literacy that will provide educational researchers with a construct sufficient to measure the very, group of vision competencies". Despite attempts to review VL definitions (Avgerinou \& Ericson, 1997; Pettersson, 2018), no consensus has been reached. A clear and agreed definition would help to explain what it means to be visually literate, and thus, move forward research on VL assessment.

\section{From Traditional Literacy to Visual Literacy}

From the beginning of VL movement, visual competencies have been described as “fundamental to normal human learning” (Fransecky \& Debes, 1972, p. 7). A decade ago, Elkins (2008) proclaimed the "time to consider the possibility that literacy can be achieved through images as well as texts and numbers" (p. 4-5). Visual literacy should finally gain equal status to alphabetic literacy and become a part of any higher education curriculum regardless of the discipline. However, universities' curricula seem to overlook this urgent need, and still rely heavily on texts with scant attention to images (except in disciplines traditionally visual, such as fine art, photography, film studies, etc.). While other forms of literacies can provide different perspectives and even deeper insights (Provenzo et al., 2011), the role and meaning of alternative literacies are often ignored. Along this line of argument, Metros and Woolsey (2006) point out that the definition of a literate person of the 21 st century should be revised and include VL skills as a core requirement. Today's world cannot be explained in purely linguistic terms (Avgerinou, 2009). Educators should, therefore, commit themselves toward education that stimulates students' visual learning and thinking strategies.

The assumption that the generation of new media users, also known as digital natives (Prensky, 2001) or millennial learners (Brumberger, 2011), is visually literate has been still taken for granted. New technologies seem to develop much faster than our ability to reflect upon our relation to them and their daily usage. As a result, although often deeply immersed into new technologies, today's learners do not necessary demonstrate skills that help them to effortlessly and effectively communicate visually (Metros \& Woolsey, 2006). Pettersson 
(2018) indicates that today's students are passive consumers of visual culture. Thus, they receive visual messages in the classroom, but are unable to actively create meaning from them. Relevant and consequent VL training have the potential to fulfill this educational gap. However, VL should first gain privileged status, especially in relation to conventional textbased literacy.

Although early definitions of VL were coined long before the prevalence of online and visually mediated communication, social media and proliferation of visual or multi-sensory devices, the call for visual education is particularly related to rapid technological changes in modern societies. The VL movement emerged because of human interaction with visual media, particularly, as an answer to the growing anxiety arising from children's increasing exposure to television. And although some of the VL definitions can be perceived as outdated, and thus, inadequate to current technological development, they still reflect the need of skills for effective visual communication. Among such referential definitions is the one proposed by Debes (1969), which Fransecky and Debes (1972) revised and has since 1989 been used by the International Visual Literacy Association as its official definition (Pettersson, 1993).

Brill et al. (2007) argue that the VL scholarly community should adopt one operational definition, which they view as a prerequisite for advancing research on the principles of VL. I argue, however, that any agreement upon a VL definition can be reached due to the multidisciplinary character of the field. Furthermore, the definitions that already exist are often similar with some discipline-specific additions. Hence, I suggest to close the debate over the concept and to do something about its implementation in education. This approach draws on the roots of VL movement and Fransecky and Debes's (1972, p. 5) call: "If you really want to understand visual literacy, you will have to do something about it".

In this study, I intend to avoid either compiling a corpus of VL definitions or advancing its theory (see Avgerinou \& Ericson, 1997; Avgerinou, 2001; Braden \& Hortin, 1982; Braden, 1993; Pettersson, 2018). I select several definitions that can be useful for education practitioners, particularly within university education. The selection includes both the more established as well as some recent definitions. I further aim to translate them into concrete learning and teaching objectives. In doing, I shall construct lists of skills (abilities, competencies) that a visually literate individual should be able to demonstrate. 
The structure of this study builds on one of the significant points of convergence among VL theorists in that visual language parallels verbal language (Avgerinou, 2001, 2009). Visual literacy is often understood as parallel to alphabetic literacy, which explains the frequently applied analogy of visual reading and writing. Avgerinou (2009) indicates that "the VL skills have been specified as (a) to read/decode/interpret visual statements, and (b) to write/encode/create visual statements" (p. 29). However, the analogy with alphabetic literacy is also perceived as "a failed metaphor" (Cassidy \& Knowlton, 1983), and thus, VL is seen as a concept that is internally and unavoidably contradictory due to its immediate reference to the act of reading images (Elkins, 2008). Consequently, the analogy to alphabetic literacy is criticized as being insufficient to describe VL. However, the reference to visual reading and writing is used in many definitions to provide familiar framework for a palette of skills that VL covers. This may also help to equalize the status, and thus also the importance, of VL in reference to conventional literacy. However, this analogy may carry the requirement to define visual vocabulary, grammar and syntax, and thus, force the description of images in semiotic terms. Visual competencies, understood as literacy, can be perceived by learners as too complex to acquire. Indeed, fluency in visual communication requires relevant training. However, some basic skills can be already acquired in any subject education if the teaching program is adequately revised and educators sufficiently prepared to include elements of VL education in their teaching practice.

\section{Visual Skills, Competencies or Abilities?}

Following the lack of agreement on VL definition and its theory, there is no clear distinction regarding vocabulary that describes comprehension in VL. Thus, the terms of ability, skill and competency are used invariably and interchangeably to explain what it means to be visually literate (Avgerinou, 2009). In some definitions, VL is initially described as (general) groups of abilities to further enumerate particular competencies or skills that are covered by these abilities (see, for instance, Fransecky \& Debes, 1972; Avgerinou, 2001, 2009).

Among all three terms, an ability (also abilities) is the one that occurs most frequently in the contexts of visual reading and writing as well as thinking and learning (the latter two abilities appear in definition by Braden \& Hortin, 1982; Hortin, 1984; Avgerinou, 2001). A skill can be defined as a learnt ability, which is acquired through systematic effort. Thus, VL 
skills are described as learnable, teachable and capable of development and improvement (Avgerinou, 2001). Intentional VL training can help learners to become visually literate and competent individuals. Competence, competency or competencies in VL enable individuals to efficiently communicate visually. Thus, individuals have the knowledge and skills for interpreting and understanding visual messages as well as using or creating them for communication purposes. Although in this article I use all three terms interchangeably regarding the definition that I refer to, I favor the term skills when introducing the results of this study, that is the three lists of VL skills. Any skill develops through practice and training — same as VL. Therefore, VL is considered here as group of skills that have practical application in various contexts, from daily social interactions to professional communication at work. VL education should be included in any basic curriculum across disciplines. In order to achieve this goal, education practitioners need to first recognize particular skills of VL and further educate visually literate individuals.

\section{Method}

The aim of this study is to discuss VL in a context of education practice, specifically in university education, and to answer the research question of What does it mean to be visually literate? For this purpose, I selected and juxtaposed VL definitions referred to frequently in scholarly publications between 1969 (Debes) and 2013 (Hattwig et al.). Besides the first and the latest ones, I selected definitions useful for university-level educators to comprehend a palette of skills that VL covers. Among eleven selected definitions there were two categories: (i) those formulated on a general level, which I called trans-disciplinary and (ii) those proposed in the more specific contexts of teaching, learning and curriculum development in higher education.

The eleven definitions differ from each other in terms of the disciplinary origin and the historical context in which they appeared. This context was the emergence of visual media and new technologies, especially television, digital photography, Internet, social media and smartphones. I reviewed the eleven definitions and grouped them into three lists of skills (abilities, competencies): visual reading skills, visual writing skills, and other visual literacy skills (see Table 1). Next, within each of these three groups, I identified thematic categories of skills that I further discuss and evaluate in relevant sections of this article. After discussion of 
Table 1. Juxtaposition of eleven VL definitions published between 1969 and 2013, grouped into three lists of skills: visual reading skills, visual writing skills and other VL skills.

\begin{tabular}{|c|c|c|c|}
\hline Source of definition & Visual reading skills & Visual writing skills & Other visual literacy skills \\
\hline Debes (1969) & $\begin{array}{l}\text { - discriminate and interpret the visible } \\
\text { actions, objects and symbols } \\
\text { - comprehension and enjoyment of } \\
\text { masterworks of visual communication }\end{array}$ & $\begin{array}{l}\text { - ability to (creatively) communicate } \\
\text { with others }\end{array}$ & \\
\hline Fransecky and Debes (1972) & $\begin{array}{l}\text { - read visuals made for intentional } \\
\text { communication } \\
\text { - translate from visual language to the } \\
\text { verbal and vice versa } \\
\text { - basic understanding of the grammar of } \\
\text { visual language } \\
\text { - developing a critical sensibility toward } \\
\text { visual communication }\end{array}$ & $\begin{array}{l}\text { - create visuals } \\
\text { - combine visuals and verbal for } \\
\text { intentional communication }\end{array}$ & - plan visuals \\
\hline $\begin{array}{l}\text { Ausburn and Ausburn } \\
\text { (1978) }\end{array}$ & - understanding visuals & $\begin{array}{l}\text { - using visuals for intentional } \\
\text { communication with others }\end{array}$ & \\
\hline Braden and Hortin (1982) & - ability to understand images & $\begin{array}{l}\text { - use images } \\
\text { - express oneself in terms of images }\end{array}$ & $\begin{array}{l}\text { - ability to think and learn in terms of } \\
\text { images }\end{array}$ \\
\hline Considine (1986) & $\begin{array}{l}\text { - the ability to comprehend images in a } \\
\text { variety of media }\end{array}$ & $\begin{array}{l}\text { - the ability to create images in a variety } \\
\text { of media } \\
\text { - the ability to communicate more } \\
\text { effectively }\end{array}$ & \\
\hline $\begin{array}{l}\text { IVLA }(1989)(\text { cited in } \\
\text { Pettersson, 1993) }\end{array}$ & $\begin{array}{l}\text { - learned ability to interpret visual } \\
\text { communication of visual symbols } \\
\text { (images) } \\
\text { - ability to evaluate information in visual } \\
\text { media } \\
\text { - ability to translate images into } \\
\text { language and vice versa }\end{array}$ & $\begin{array}{l}\text { - ability to create messages using visual } \\
\text { symbols }\end{array}$ & - ability to search for visual information \\
\hline
\end{tabular}




$\begin{array}{ll}\text { Box and Cochenaur (1995) } & \text { - evaluation of visual messages } \\ \text { - skills that prospective } & \text { (informed interpretation of visual } \\ \text { teachers should have } & \text { media, including mass media) }\end{array}$

- skills that prospective
- creating visual images (design and production of visual materials in a variety of media, proper use of visual communication elements)

- proper use of ready-made visual instructional materials
- visual perception and visual learning processes (visual thinking, visualization, perceptual theories such as dual coding, visual symbolism, and visual learning styles)

- proper selection of ready-made visual instructional materials

- abilities to learn in terms of images

- abilities to think in terms of images (i.e. to think visually)

\begin{tabular}{|c|c|c|c|}
\hline $\begin{array}{l}\text { Hortin (1984) and } \\
\text { Avgerinou (2001) }\end{array}$ & - abilities to understand (read) images & - abilities to use images (write) & $\begin{array}{l}\text { - abilities to learn in terms of images } \\
\text { - abilities to think in terms of images (i.e. } \\
\text { to think visually) }\end{array}$ \\
\hline Metros and Woolsey (2006) & $\begin{array}{l}\text { - ability to look at imagery } \\
\text { - ability to perceive meaning } \\
\text { - ability to make decision based on what } \\
\text { you see }\end{array}$ & $\begin{array}{l}\text { - ability to make simple images } \\
\text { - ability to visualize basic data }\end{array}$ & \\
\hline Felten (2008) & $\begin{array}{l}\text { - ability to understand culturally } \\
\text { significant images, objects, and visible } \\
\text { actions } \\
\text { - ability to recognize and interpret the } \\
\text { distinct syntax and semantics of } \\
\text { different visual forms }\end{array}$ & $\begin{array}{l}\text { - ability to produce and use culturally } \\
\text { significant images, objects, and visible } \\
\text { actions } \\
\text { - ability to employ the distinct syntax and } \\
\text { semantics of different visual forms }\end{array}$ & \\
\hline Hattwig et al. (2013) & $\begin{array}{l}\text { - interpret and analyze images } \\
\text { - evaluate images }\end{array}$ & $\begin{array}{l}\text { - create visual media } \\
\text { - use images effectively } \\
\text { - use images ethically }\end{array}$ & $\begin{array}{l}\text { - find images } \\
\text { - define image need } \\
\text { - cite visuals }\end{array}$ \\
\hline
\end{tabular}


skills, I provide some examples of visual practices through which individuals can demonstrate particular skills.

Finally, I suggest how the results of this study - the lists of VL skills - can be used toward development of formal visual education. The discussion is illustrated by additional figures (a word cloud, a mind map of skills and types of visuals), generated from the study's results. These figures should help the reader to visualize, and thus, to comprehend the reviewed definitions.

\section{Toward a Visually Literate Individual}

For those who can see, seeing is one of the most natural acts. Socializing and learning occurs by observation and acting. Our experience and perception of the world, choices that we make, individual preferences and fears are greatly organized by what we see. However, for an effective visually mediated communication, our gaze should be trained. Visual literacy is not a naturally occurring competency, acquired while frequently encountering images of various kinds. The VL concept combines skills in visual reading (interpreting, meaning making), visual writing skills (using or creating images) as well as visual thinking and learning abilities, and other VL skills.

Although the definitions juxtaposed in this study mostly use a metaphor of visual reading and writing, not all skills easily undergo this categorization. This tendency may further indicate that VL is a failed metaphor as already suggested by Cassidy and Knowlton (1983), and which I also discuss in this article. Nevertheless, the lists of VL skills that I propose are also combined using the division into visual reading and writing, but with some limitations indicated.

Next, I evaluate the three groups of VL skills (see Table 1) with the thematic categories identified within each group. I also provide some further suggestions regarding the context of everyday visual communication, for which various skills are required. Additionally, I advise how those skills can be developed in visual education.

\section{Visual Reading Skills}

The visual reading skills can be divided into five thematic groups: interpreting, analyzing and understanding; visual perception; evaluation; knowledge of grammar and syntax; translation (visual-verbal-visual) (see Table 2). The interpretation skill is described as 
Table 2. Visual reading skills grouped thematically. Based on review of eleven VL definitions published between 1969 and 2013 (see Table 1).

\section{Visual reading skills}

\begin{tabular}{|c|c|c|c|c|}
\hline $\begin{array}{l}\text { interpretation, analysis, } \\
\text { understanding }\end{array}$ & visual perception & evaluation & $\begin{array}{c}\text { knowledge of grammar and } \\
\text { syntax }\end{array}$ & $\begin{array}{c}\text { translation } \\
\text { (visual-verbal-visual) }\end{array}$ \\
\hline $\begin{array}{l}\text { interpret the visible actions, } \\
\text { objects and symbols } \\
\text { read visuals made for } \\
\text { intentional communication } \\
\text { understand (read) images/ } \\
\text { visuals } \\
\text { comprehend images in a } \\
\text { variety of media } \\
\text { learned ability to interpret } \\
\text { visual communication of } \\
\text { visual symbols (images) } \\
\text { informed interpretation of } \\
\text { visual media, including } \\
\text { mass media } \\
\text { perceive meaning } \\
\text { understanding culturally } \\
\text { significant images, objects, } \\
\text { and visible actions } \\
\text { interpret and analyze images }\end{array}$ & $\begin{array}{l}\text { - discriminate the visible } \\
\text { actions, objects and symbols } \\
\text { - comprehension and } \\
\text { enjoyment of masterworks } \\
\text { of visual communication } \\
\text { - ability to look at imagery } \\
\text { - developing a critical } \\
\text { sensibility toward visual } \\
\text { communication }\end{array}$ & $\begin{array}{l}\text { - evaluate information in } \\
\text { visual media } \\
\text { - evaluate visual messages/ } \\
\text { images } \\
\text { - making decision based on } \\
\text { what you see }\end{array}$ & $\begin{array}{l}\text { - basic understanding of the } \\
\text { grammar of visual language } \\
\text { recognize and interpret the } \\
\text { distinct syntax and } \\
\text { semantics of different visual } \\
\text { forms }\end{array}$ & $\begin{array}{l}\text { translate from visual } \\
\text { language to the verbal and } \\
\text { vice versa } \\
\text { - translate images into } \\
\text { language and vice versa }\end{array}$ \\
\hline
\end{tabular}


a learned ability or informed interpretation. This feature refers to the notion that VL skills are learnable, teachable and capable of development and improvement (Avgerinou, 2001).

Regarding the object of interpretation, definitions specify visible actions, objects and symbols, and images, which are also described as culturally significant images (Felten, 2008), and visuals and visual media that include mass media. The palette of visual objects that undergo visual interpretation is very broad and includes not only various kinds of still images, but also the so-called visible actions (Debes, 1969; Felten, 2008) that are not further explained. Visual literacy is essential for everyday conscious encounter with everything we see. In this context, part of visual learning occurs naturally, or through informal processes by observation of norms and behaviors. However, further education is required when it comes to:

- the ability to recognize manipulated visual content;

- decoding advertisements, that is, being able to easily distinguish between advertisements and other kinds of images as well as being able to indicate visual elements that are used to sell certain product or service;

- providing interpretation of an image (e.g. journalistic photograph, painting) that goes beyond simple description of what is in the picture;

- understanding and being able to follow pictorial instructions such as instructions of assembling furniture, recognizing transnational symbols, etc.

Furthermore, some definitions indicate an ability to understand culturally significant images (Felten, 2008), which requires cultural image literacy (Emanuel et al., 2014, 2016), that is, an ability to recognize images related to, or significant for, the viewer's culture. In this context, we may also think about shared cultural image literacy, that is, knowledge and ability to read and interpret universal visual codes within images meant for a wider or international audience, such as advertisements and some iconic journalistic photographs.

Once viewers can understand and interpret images, they would also broaden their visual perception skills. Individuals may develop strategies toward comprehension and enjoyment of various forms of artistic representations. Similarly, visually literate individuals should be able to evaluate visual information they receive and make decisions based on what they look at and interpret.

As indicated earlier, some skills that VL definitions bring up are built on the assumption that visual language parallels verbal language. Thus, the need for knowledge of 
Table 3. Visual writing skills grouped thematically. Based on review of eleven VL definitions published between 1969 and 2013 (see Table 1).

\section{Visual writing skills}

\begin{tabular}{|c|c|c|}
\hline visual communication & visual creation and image production & image use \\
\hline $\begin{array}{l}\text { - communicate (creatively) with others } \\
\text { - combine visuals and verbal for intentional } \\
\text { communication } \\
\text { - using visuals for intentional communication with } \\
\text { others } \\
\text { - express oneself in terms of images } \\
\text { - propility to communicate more effectively }\end{array}$ & $\begin{array}{l}\text { - } \text { create visuals/visual media } \\
\text { - create images in a variety of media } \\
\text { - create messages using visual symbols } \\
\text { - creating visual images: design and production of } \\
\text { visual materials in a variety of media } \\
\text { - make simple images } \\
\text { - visualize basic data } \\
\text { - produce culturally significant images, objects, and } \\
\text { visible actions }\end{array}$ & $\begin{array}{l}\text { - use images (write) } \\
\text { - use images effectively } \\
\text { - use images ethically } \\
\text { - proper use of ready-made visual instructional } \\
\text { materials } \\
\text { - use culturally significant images, objects, and } \\
\text { visible actions } \\
\text { - employ the distinct syntax and semantics of } \\
\text { different visual forms }\end{array}$ \\
\hline
\end{tabular}

Table 4. Other VL skills grouped thematically. Based on review of eleven VL definitions published between 1969 and 2013 (see Table 1).

\section{Other visual literacy skills}

\begin{tabular}{|c|c|c|}
\hline visual thinking & visual learning & applied image use \\
\hline $\begin{array}{l}\text { - abilities to think in terms of images (i.e. to think } \\
\text { visually)/visual thinking }\end{array}$ & $\begin{array}{l}\text { - abilities to learn in terms of images } \\
\text { visual learning processes: visualization, perceptual } \\
\text { theories such as dual coding, visual symbolism, } \\
\text { and visual learning styles }\end{array}$ & $\begin{array}{l}\text { - plan visuals } \\
\text { - searching for visual information } \\
\text { - proper selection of ready-made visual instructional } \\
\text { materials } \\
\text { - find images } \\
\text { - define image need } \\
\text { - cite visuals }\end{array}$ \\
\hline
\end{tabular}


visual grammar, syntax and relevant visual vocabulary is expressed in some of the definitions (Fransecky \& Debes, 1972; Felten, 2008). Avgerinou (2009) lists the knowledge of visual vocabulary as the first of the eleven VL competencies and explains it as "knowledge of basic components (i.e. point, line, shape, form, space, texture, light, color, motion) of visual language" (p. 29). Indeed, the relevant vocabulary can be useful when verbalizing the result of an image interpretation process. However, the knowledge of grammar, syntax and semantics of visual language is quite vague and maybe too advanced for basic VL education. Still within the metaphor of visual language, some definitions indicate an ability to translate images into verbal language and vice versa (Fransecky \& Debes, 1972; Pettersson, 1993). The ability to translate images should be more broadly understood than visual interpretation skills from the first thematic category. To translate an image into verbal language means providing comprehensive understanding and analysis of certain visual communications and vice versa; in other words, being able to produce image(s) that communicate the meaning of written (or verbal) text.

\section{Visual Writing Skills}

The skills in visual writing are divided into three thematic groups of visual communication, visual creation and image production, and image use (see Table 3). Accordingly, visual writing is defined not only as an image creation process, but also as an ability to use visuals for intentional communication. The definitions imply that images are used to communicate more creatively (Debes, 1969), or to express oneself in terms of images (Braden \& Hortin, 1982). Visual writing is an ability that allows individuals to communicate more effectively using either visuals or by combining visuals with verbal. Thus, any teaching activities in visual storytelling that enable learners to communicate in a sequence of still or moving images, may help to develop visual communication skills. Additionally, creating a basic visual collage or infographic may act as simple introductory activities in visual writing.

Next is a group of skills in visual creation and image production. The analyzed definitions suggest a palette of objects that visually literate individual should be able to create, from simple images, through messages using visual symbols to visualizing basic data, creating visual media and culturally significant images. However, some definitions describe visual writing simply as image creation and do not specify any kinds of visual production, and thus, a required level of competency in visual writing. Thus, it might be useful to indicate the 
kind of knowledge that an individual acquires when successfully completing visual writing tasks. These may include basic knowledge in visual framing and composition, the ability to visualize thoughts and ideas, reaching coherence in created visuals (for instance, in slide presentations, charts, diagrams, tables, etc.).

When describing skills in visual writing, the definitions frequently refer to (visual) media production. However, in many cases this would require professional training that may not necessarily be a part of basic university curricula across disciplines. Some skills in photographing or filmmaking are usually acquired in contexts other than formal education. Nevertheless, formal education can improve those skills via formal schooling, especially that definitions do not specify what kind of media production and its comprehension is required.

Visual creation skills include production and usage of culturally significant images, objects or visible actions (Felten, 2008). This requirement is quite vague due to the difficulty in defining the significant nature of visuals unless they are, for instance, iconic journalistic photographs, international symbols or logos. Their significance is mostly an outcome of timing and publicity. Thus, in a context of VL education, I opt for the ability of using culturally significant visuals rather than producing them. This ability again refers to aforementioned cultural image literacy.

A separate group consists of skills in image use. Some definitions (Avgerinou, 2001; Braden \& Hortin, 1982; Hortin, 1984) describe visual writing as image use rather than image creation. In courses that are not primarily focused on VL, the skills required for relevant usage

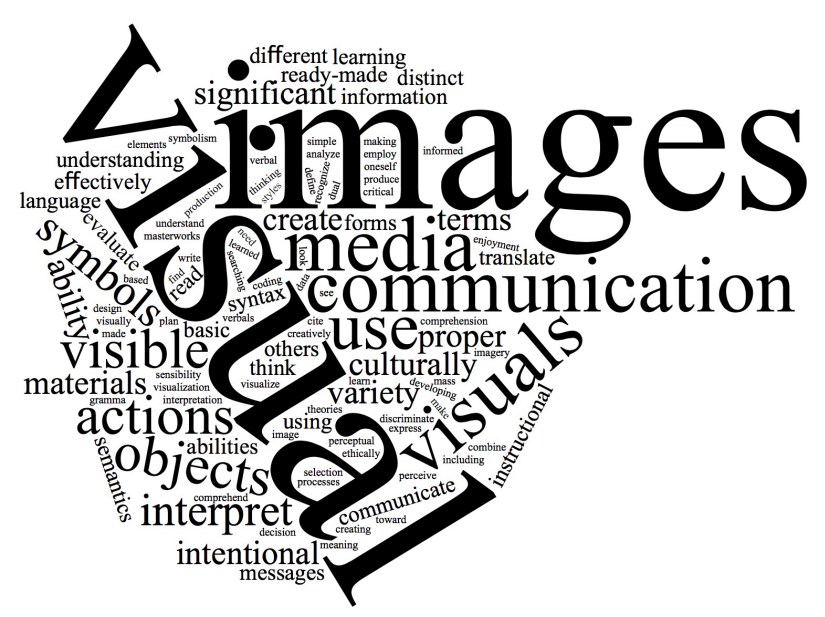

Figure 1. Word cloud of VL skills, generated from the content of Tables 2, 3 and 4, and based on the review of VL definitions published between 1969 and 2013. 
of images are easier to develop along the main content of subject education. The definitions suggest that visually literate individuals should use images properly, effectively and ethically, with respect to their visual nature and in so doing employ the distinct syntax and semantics of different visual forms (Felten, 2008). Concomitant with a proper and ethical use of images comes awareness and knowledge of consequences related to dissemination of images via channels of visually mediated communication, such as social media. Development of skills in image use should be a part of learning objectives of any courses, whenever visuals are displayed, shared or discussed in classroom activities.

\section{Other Visual Literacy Skills}

Other VL skills involve visual thinking, visual learning and applied image use (see Table 4), which combine to confirm the earlier argument that VL, as a metaphor of visual reading and writing, is too narrow. Competency in visual thinking is the result of visual education - the more learners interact with images in a systematic way, the more they learn to see. Similarly, abilities to learn in terms of images develop along the process of visual education. Thus, competency in visual thinking and learning is not simply a consequence of daily encounters with images. This mistaken assumption was already disproved in studies on digital natives and their frequent encounter with visual technologies (Brumberger, 2011; Metros \& Woolsey, 2006).

Within the group of other VL skills is a list that I labeled applied image use, meaning a very concrete, practical application of images that is rarely verbalized in the reviewed definitions. According to that list, visually literate individuals know how to cite visuals, with respect to ethical and copyright issues and can spot a need for visual material, for example, in a presentation, followed by search strategies for relevant images. Thus, learners should not only know where and how to look for visual information, but also be able to select relevant visuals as well as to plan image use.

\section{Toward Application of Lists of Visual Literacy Skills}

A decade ago Elkins (2008, p. 8) proclaimed that "images are central to our lives, and it is time they become central in our universities". If so, the question remains how the goal of image-centered tertiary education should be achieved, especially in the fields of study that are not inherently visual. Or maybe VL should be a part of common basic curricula for all first year undergraduates. Whichever way visual education enters tertiary education, it will further 
Figure 2. Types of visuals to work with in VL education, based on the review of VL definitions published between 1969 and 2013.

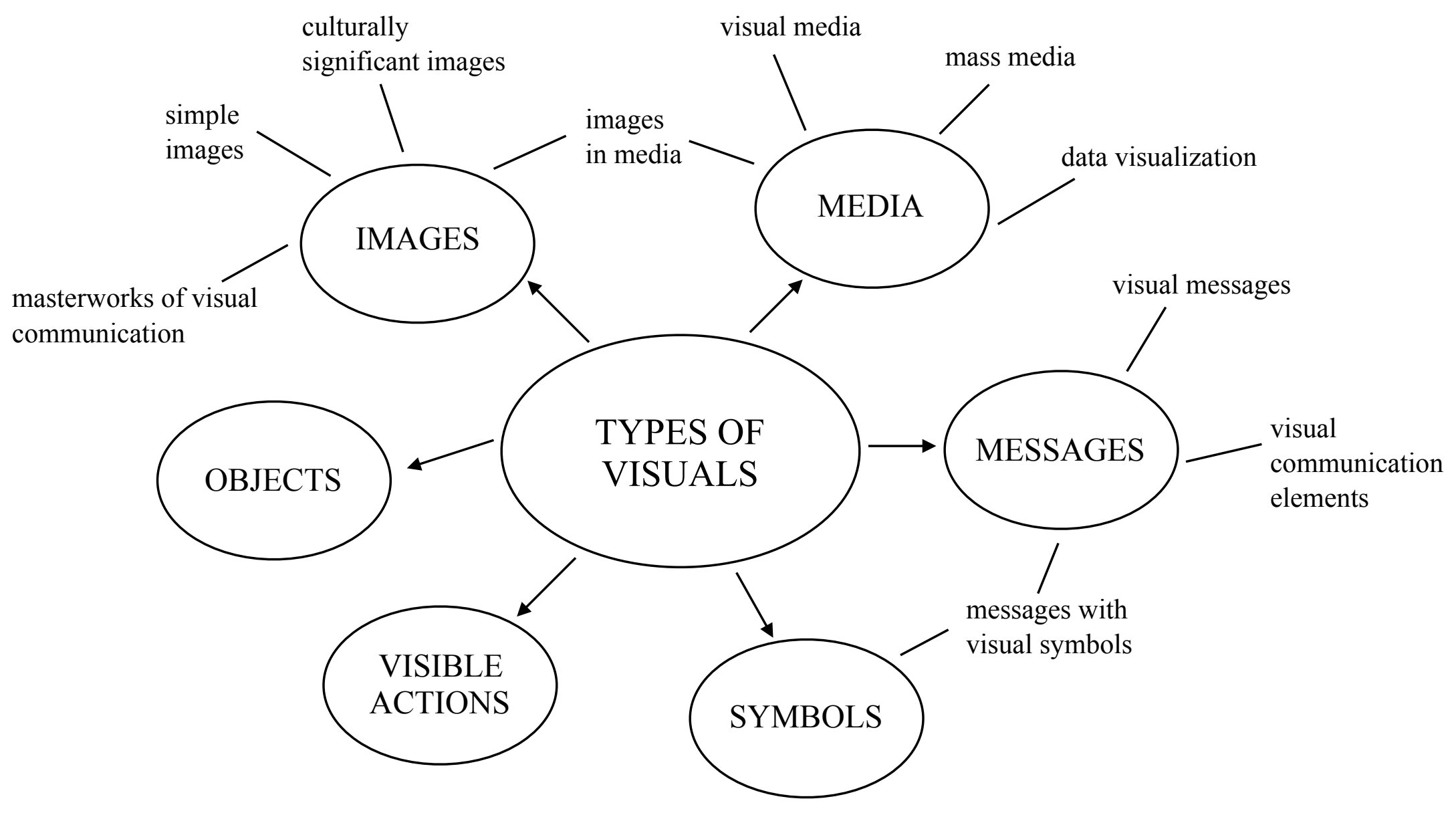


require a definition of learning objectives. For that purpose, the lists of VL skills that were formulated in this study can be of use. Although some of the listed skills may require further elaboration or inclusion of concrete practical examples, they give teachers better possibilities to focus on certain areas of VL.

Nevertheless, when considering more systematic and comprehensive VL education, it may be challenging to choose and decide which skills and how many of them learners should acquire. The amount and variety of VL skills is overwhelming with a constant reference to visuals, images, media and communication (see Figure 1). They also differ in degree of difficulty. Thus, for instance, some definitions require skills in creating simple images (Metros \& Woolsey, 2006), while others describe visual writing as ability to produce culturally significant images (Felten, 2008), or to design and produce visual materials in a variety of media (Box \& Cochenaur, 1995). Indeed, the definitions juxtaposed in this study refer to many kinds and types of visuals as objects of visual education (see Figure 2). The choice of images should be dictated by teaching needs and context, as well as learners' experience, knowledge and background. Fransecky and Debes (1972) suggest that instead of continuous theorizing about VL, the real experience may actually expand the sense of VL's validity and value. They call for some real action towards VL development that is required for a comprehensive understanding of the concept. Thus, so long as any kind of intentional and systematic visual education occurs in universities, it is possible to develop students' VL. The types of visuals used to achieve this goal are of secondary importance.

However, the questions remain as to what the required level of comprehension of VL skills would be and how to measure it? Based on learning objectives and in unity with a course design, a teacher can create a rubric for grading purposes (as an example, see VL competency rubric by Bowen, 2017). On the other hand, if the challenge of systematic visual education is taken seriously and prospectively, there is a need for an assessment method of VL. The lists of skills that this study compiled can be helpful in designing a method of assessment, regardless of the discipline or the students' field of study. Currently, I suggest focusing on equal development of visual competency within each of the three groups of skills and related thematic categories (see Figure 3 for an overview and Tables 2, 3 and 4 for details). 
Figure 3. Three categories of VL skills with thematic groups of skills.

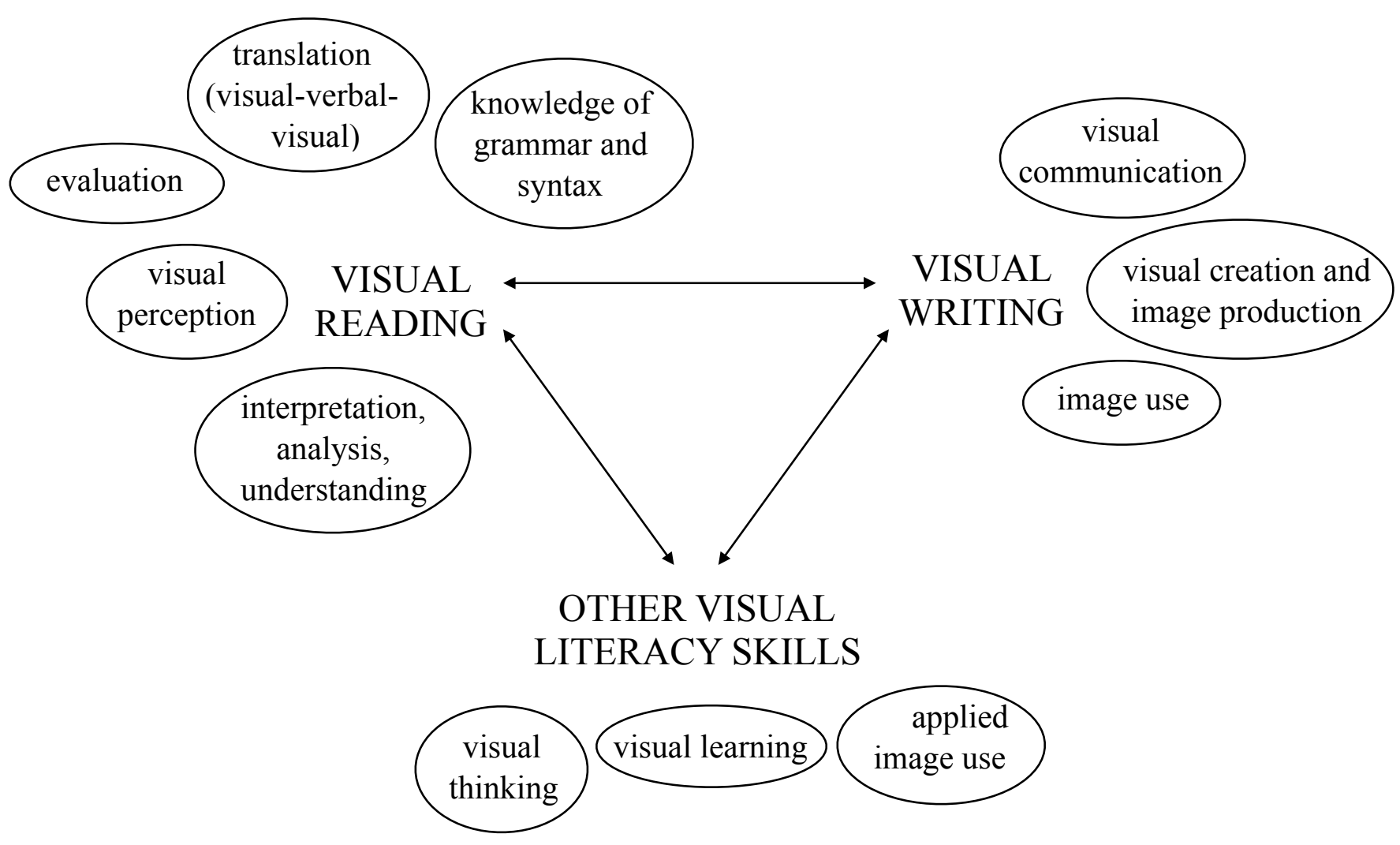




\section{Conclusion}

This study attempted to answer the question of what it means to be visually literate. The question may be more precisely formulated as: What are the skills, abilities and competencies that visually literate individuals should demonstrate. The study was conducted in a vacuum of selected VL definitions, and thus, provides answers immersed in theory rather than practice. The study may, therefore, act as a starting point for further research on VL education. The lists of VL skills developed in this study can be used as basis for defining learning objectives in visual education, or for creating a method of VL assessment.

Considering the lack of agreement upon VL theory and instead of raising yet more confusion regarding its definition, this study provided in-depth analysis of existing literature. Thus, starting from the earliest to the most recent ones, I juxtaposed eleven definitions of VL, formulated from various historical and disciplinary perspectives. As a result, I compiled lists of skills in visual reading and writing as well as other VL skills that visually literate individuals should, ideally, demonstrate. Further research may then determine which of these skills, at what level of comprehension, should be mastered via systematic visual education. Moreover, having the lists of VL skills at hand, it is possible to create an assessment method, which is urgently needed not only for grading purposes, but also to demonstrate that formal and systematic visual education is of critical need in today's universities.

\section{References}

Association of College and Research Libraries (ACRL). (2011). ACRL Visual Literacy Competency Standards for Higher Education. American Library Association. Retrieved from: http:// www.ala.org/acrl/standards/visualliteracy

Ausburn, L.J. \& Ausburn, F.B. (1978). Visual literacy: Background, theory and practice. Innovations in Education \& Training International, 15(4), pp. 291-297.

Avgerinou, M.D., \& Ericson, J. (1997). A review of the concept of visual literacy. British Journal of Educational Technology, 28(4), 280-291.

Avgerinou, M.D. (2001). Visual literacy: Anatomy and diagnosis (Unpublished doctoral dissertation). University of Bath, UK.

Avgerinou, M.D. (2009). Re-viewing visual literacy in the "Bain d' Images" era. TechTrends: Linking Research and Practice to Improve Learning, 53(2) March/April, 28-34. 
Avgerinou, M.D., \& Pettersson, R. (2011). Toward a cohesive theory of visual literacy. Journal of Visual Literacy, 30(2), 1-19.

Bleed, R. (2005). Visual literacy in higher education. EDUCAUSE Learning Initiative Explorations, 1, 1-11. Retrieved from https://net.educause.edu/ir/library/pdf/ eli4001.pdf

Bowen, T. (2017). Assessing visual literacy: A case study of developing a rubric for identifying and applying criteria to undergraduate students learning. Teaching in Higher Education, 22(6), 705-719, doi: 10.1080/13562517.2017.1289507.

Box, C, \& Cochenaur, J. (1995). Visual literacy: What do prospective teachers need to know? Imagery and Visual Literacy: Selected Readings from the Annual Conference of the International Visual Literacy Association (26th, Tempe, AZ, October 12-16, 1994), 1-10. ERIC Document Reproduction Service No. ED 380059.

Braden, R.A. (1993). Twenty-five years of visual literacy research. Visual Literacy in the Digital Age: Selected Readings from the Annual Conference of the International Visual Literacy Association (25th, Rochester, NY, October 13-17, 1993), 1-14. ERIC Document Reproduction Service No. ED 370548.

Braden, R.A., \& Hortin, J.A. (1982). Identifying the theoretical foundations of visual literacy. In R.A. Braden \& A.D. Walker Television and visual literacy. Bloomington, IN: International Visual Literacy Association. ERIC Document Reproduction Service No. ED 233677.

Brill, J.M., Kim, D., \& Branch, R.M. (2007). Visual literacy defined - The results of a Delphi Study: Can IVLA (operationally) define visual literacy? Journal of Visual Literacy, 27(1), 47-60.

Brumberger, E. (2011). Visual literacy and the digital native: An examination of the millennial learner. Journal of Visual Literacy, 30(1), 19-46.

Brumberger, E., \& Northcut, K. (2013). Designing Texts: Teaching Visual Communication. Baywood Publishing.

Cassidy, M., \& Knowlton, J. (1983). Visual literacy: A failed metaphor? Educational Communication and Technology, 31(2), 67-90.

Chauvin, B.A. (2003). Visual or media literacy? Journal of Visual Literacy, 23(2), 119-128. 
Considine, D.M. (1986). Visual literacy and children's books: An integrated approach. School Library Journal, September, 38-42.

Debes, J.L. (1969). The loom of visual literacy: An overview. Audiovisual Instruction 14(8), 25-27.

Elkins, J. (2008). Introduction: The concept of visual literacy and its limitations. In J. Elkins (ed.), Visual literacy, 1-9. New York: Routledge.

Emanuel, R., Baker, K., \& Challons-Lipton, S. (2014). The 'Cultural Image Literacy Assessment': One hundred images every American should know. The Journal of American Culture, 37(4), 404-418.

Emanuel, R., Baker, K. and Challons-Lipton, S. (2016). Images every American should know: developing the 'Cultural Image Literacy Assessment-USA'. Journal of Visual Literacy, $35(4), 215-236$.

Ervine, M.D. (2016). Visual literacy in instructional design programs. Journal of Visual Literacy, 35(2), 104-113.

Felten, P. (2008). Visual literacy. Change, 40(6), 60-64.

Fransecky, R.B., \& Debes, J.L. (1972). Visual literacy: A way to learn - a way to teach. Washington, DC: Association for Educational Communications and Technology.

Griffin, M. (2008). Visual competence and media literacy: can one exist without the other? Visual Studies, 23(2), 113-129.

Hattwig, D., Bussert, K., Medaille, A., and Burgess, J. (2013). Visual Literacy Standards in Higher Education: New opportunities for libraries and student learning. Portal: Libraries and the Academy, 13(1), 61-89.

Hortin, J.A. (1984). Visual literacy and visual thinking. In L. Burbank \& D. Pett (Eds.) Contributions to the study of visual literacy. IVLA.

Kędra, J. (2016). Interpretation of journalistic photographs as an instrument of visual literacy education (Doctoral dissertation, Jyväskylä Studies in Humanities 297, University of Jyväskylä, Finland). Retrieved from http://urn.fi/URN:ISBN:978-951-39-6796-3.

Little, D., Felten, P., \& Berry, C. (Eds.). (2015). Looking and learning: visual literacy across the disciplines. San Francisco, CA: Jossey-Bass.

Metros, S.E, \& Woolsey, K. (2006). Visual literacy: An institutional imperative. EDUCASE Review, 41(3) (May/June), 80-81. 
Müller, M.G. (2008). Visual competence: A new paradigm for studying visuals in the social sciences? Visual Studies, 23(2), 101-112.

Pettersson, R. (1993). Visual Information (2nd ed.). Englewood Cliffs, NJ: Educational Technology Publications.

Pettersson, R. (2018). Information Design - Image Design. Tullinge: Institute for Infology.

Prensky, M. (2001). Digital natives, digital immigrants. On the Horizon, 9(5), 1-6.

Provenzo, Jr., E.F., Goodwin, A., Lipsky, M., and Sharpe, S. (Eds.) (2011). Introduction: Literacy for the 21st century. In E.F. Provenzo, Jr., A. Goodwin, M. Lipsky \& S. Sharpe (Eds.) Multiliteracies: Beyond Text and the Written Word. Charlotte, NC: Information Age Publishing.

Riddle, J. (2009). Engaging the eye generation: Visual literacy strategies for the K-5 classroom. Portland, ME: Stenhouse Publishers.

Serafini, F. (2014). Reading the Visual: An Introduction to Teaching Multimodal Literacy. New York (NY): Teachers College Press.

Spalter, A.M., and van Dam, A. (2008). Digital visual literacy. Theory into Practice, 47(2), 93-101. doi: 10.1080/00405840801992256

Wagner, E., \& Schönau, D. (Ed.) (2016). Common European Framework of Reference for Visual Literacy-Prototype. Münster: Waxmann. 